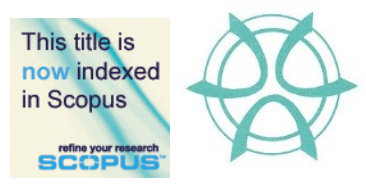

\title{
REVEALING THE INVESTMENT VALUE OF PENANG HERITAGE PROPERTIES
}

\author{
Chin Tiong Cheng ${ }^{1}$, Yan Bin Tan ${ }^{2}$, Wai Fang Wong ${ }^{3}$, Kong Seng Lai ${ }^{4}$, Koh \\ Yu Xuan ${ }^{5}$ \\ ${ }^{1,3,4}$ Centre for Construction Research (CCR) \\ ${ }^{2}$ Centre for Data Science and Analytics \\ ${ }^{1,3,4}$ Faculty of Built Environment \\ ${ }^{2}$ Faculty of Computing and Information Technology \\ TUNKU ABDUL RAHMAN UNIVERSITY COLLEGE
}

\begin{abstract}
Heritage buildings are a representation of historic features and the Malaysian culture. The intangible value of a heritage property comprises aesthetic quality, spiritual aspects, social functions, and its own uniqueness. Therefore, heritage properties have been seen to be moving away from traditional alternative investments, which are not covered by conventional real estate schemes. Additionally, the characteristics of heritage properties are expected to be seen as 'art', and they offer a highly beneficial diversification strategy with a relatively low correlation towards traditional assets classes. The Penang (Island) Heritage Property Price Index (PPHPPI) is estimated to be using a hedonic regression method. Based on the index, the heritage property records the highest quarterly returns and risk among the conventional assets considered in this study.
\end{abstract}

Keywords: Heritage property, investment, price index, diversification

\footnotetext{
${ }^{1}$ Senior Lecturer at Tunku Abdul Rahman University College. Email: chengct@tarc.edu.my
} 
PLANNING MALAYSIA

Journal of the Malaysia Institute of Planners (2021)

\section{INTRODUCTION}

Real property is viewed as a conservative investment asset because it is more resilient to short term volatility in economic conditions. Based on past studies, property investment had been used to hedge against the inflation of a particular country. The property types included residential (Li and Ge, 2008; Lee, 2014), commercial (Limmack and Ward, 1988; Newell, 1996; Fraser, Leishman and Tarbert, 2002; Leung, 2010) and industrial (Tarbert, 1996). Therefore, most of the investors preferred to invest in such properties in order to diversify the risk of investment. Tan and Ting (2004) found that Malaysia had allocated about 50\%$65 \%$ of the available capital for investing in residential property. According to the National Property Information Centre (NAPIC) (2019), the total value of property transactions were worth RM 68.30 billion in the first half of 2019. The large amount of transaction value showed the significance of the property sector towards Malaysia's economy. Additionally, the three folds increase of pre-war properties prices in Georgetown, Penang, has gained the attention of the practitioners since its recognition as a UNESCO World Heritage in 2008 (The Edge 2017).

\section{RESEARCH BACKGROUND}

In year 2008, UNESCO World Heritage had recognised Georgetown as one of the heritage cities in Malaysia. In order to manage the heritage buildings effectively, the local government had subsequently divided the heritage area into core zone and buffer zone. Besides, the landlords who intended to restore the condition of the heritage buildings in these zones, they are required to obtain the approval from the local authorities (Heritage Department of the Penang Island City Council). Jasme et.al (2014) stated that the guidelines in preserving the prewar properties included forecourt, roof, external, and internal parts of the building. According to Lum (2018) and Rahman (2018), some of the landlords of these heritage properties transformed the old buildings into much more valuable properties. For instance, cafés, boutique hotels, restaurants, and others. There are only 4,665 units of heritage buildings in the core zone and buffer zones, with a size of 109.38 hectares and 150.04 hectares respectively, in Penang (Jasme et.al.,2014). Hence, the property value of heritage buildings have been rising faster than unprotected or undefined buildings, due to the limited supply of heritage buildings (Gilderbloom et.al.,2009).

The conventional property investment in terms of risk and returns have been widely discussed in previous studies. However, the heritage properties have been given less attention in the developing investment portfolio. For example, there are some studies which explored the factors which influenced the price of these heritage properties (Shipley, 2000; Ashworth, 2002; Kouwenberg and Zwinkels, 2014; Lazrak et al., 2014). Some research was conducted on the conservation of heritage properties in order to protect its value (Billington, 2004; 
Chin Tiong Cheng, Yan Bin Tan, Wai Fang Wong, Kong Seng Lai, Koh Yu Xuan

Revealing The Investment Value of Penang Heritage Properties

Samadi and Yunus, 2012; Tokede, Udawatta and Luther, 2018). The conservation of heritage properties is necessary because these buildings can produce aesthetic and spiritual value which cannot be found in the conventional properties such as terrace houses, apartments, etc (Cores, Assets and Development, 2012; Halim and Tambi,2021). Moreover, Shipley (2000) claimed that the heritage properties were able to outperform the general market trend in terms of sales rate and value, especially during the economic downturns. This result was also supported by Mat Zin et.al (2018), from which there was evidence of an increasing trend in the price per square foot for the heritage shophouses in the long run. Hence, this study hypothesised that the heritage buildings shared the characteristics of art, from which the heritage property was embedded as an intangible value. Therefore, the correlation between heritage property and traditional asset classes were expected to be low.

Furthermore, it is important to construct a price index for measuring the performance of the Penang heritage properties, but the construction of such heritage property price indexes is indeed complicated due to the heterogeneous characteristics of these properties in terms of location and land size. The property price index should be effectively captured in the price change based on the supply and demand forces, rather than the quality change in each transacted period (Rosen, 1974). The quality change of the transacted properties must be controlled in order to avoid the price index from being overstated or understated in the price change across every period. Lazrak et al (2014) adopted the spatial autoregressive model to investigate the impact of cultural heritage on the value of the real estate in the cities. Both structural and spatial characteristics of the property were used to construct the model. The study found that the structural characteristics (e.g. number of rooms, floor space, and capacity) and spatial characteristics (e.g. population density, percentage ethnic, and proportion of water areas) had a significant impact on the property's value. According to the study, it is crucial to identify significant variables in the hedonic price index model in order to avoid the model being mis specified, or overfitted.

According to NAPIC (2019), there are several published indices for the housing sector, such as terraced, high-rise, detached, and semi-detached. Ting et.al (2007) conducted a study on the real estate returns using the published indices, and they found that the property market in Malaysia is relatively homogeneous. The diversification effect in the portfolio is not established across property type and geographical region. In terms of commercial properties, Callender et.al (2007) claimed that the risk reduction in the commercial property investment can be realised with a portfolio of $30-50$ properties. Furthermore, previous studies on the commercial property market in the United Kingdom showed that the log returns and standard deviations of the transaction-based rental series were estimated to be 15.60 percent and 35.64 percent, respectively (Patel and Sing, 2000). Brown \& Matysiak (1995) stressed that there was a correlation 
PLANNING MALAYSIA

Journal of the Malaysia Institute of Planners (2021)

between a reliable property index, and the performance measurement. In other words, a reliable price index is needed to yield precise measurements on the risk and return of such a property. The study indicated that the price index is an effective indicator in terms of making strategic decisions. However, the investigation on the investment performance of such heritage properties were not possible without the presence of heritage property price indexes.

The computation of risk and return for every asset is crucial in developing an investment portfolio. The risk of an investment asset can be measured based on its variance or standard deviation. Elton \& Gruber (1997) pointed out that the Markowitz Modern Portfolio Theory had considered the trade-off between the mean and variance of the assets. The theory aimed to maximise the expected return, and minimise the variance of the portfolio through the formulation of an efficient frontier. Thereafter, it was adopted to improve conventional investment portfolio that consists of shares, real estate security, bonds, cash, commodity, real estate and etc. (Ghazali et.al., 2015; Hiang Liow \& Adair, 2009; Jin, Grissom, \& Ziobrowski, 2007; Lee, 2007). Furthermore, a few studies found that artwork could be included for reducing the risk in an investment portfolio. It was mainly contributed by low correlation on return between artwork and financial assets. (Worthington and Higgs, 2004; Campbell, 2009). Therefore, it would be interesting to assess the aesthetic value of heritage properties from the aspect of investment. (de la Torre, 2013). Apart from that, the conservation of a historic core can also distinguish the city from competing locations (both national and international), in order to attract investment and talented people.

\section{RESEARCH METHODOLOGY}

This study listed 1084 transacted Georgetown pre-war properties from 2009Q1 until 2018Q4 (10 years or 40 quarters) for constructing a Penang (Island) Heritage Property Price Index (PPHPPI). It was used to evaluate the performance of the heritage property market in Penang's Georgetown over the past 10 years. The raw transaction data underwent data cleaning before the construction of a price index. It is important to ensure that the transacted value qualified within the definition of market value, and that the non-arm's length transactions were removed from the price index basket. In addition, this study only included the pre-war properties that held a freehold status, because the transaction volume of the leasehold properties were very low and not significant. Besides, the transacted value was based on the individual share of the property. The land size, location, and transacted months were collected from the raw transaction data, correlated (positive or negative) with the heritage property prices based on the statistical results.

The Hedonic Regression Method (HRM) is a fundamental approach in developing a price index model for heritage properties, as it is useful in 
Chin Tiong Cheng, Yan Bin Tan, Wai Fang Wong, Kong Seng Lai, Koh Yu Xuan

Revealing The Investment Value of Penang Heritage Properties

overcoming the quality change of the properties across the period. Moreover, this technique had been widely used in determining the contribution of different characteristics on house price, wage levels, and environmental quality (Palmquist et.al., 2001). The approach can be further extended to a Hedonic Time-Dummy Regression Method (HTDRM) for computing the Heritage Property Price Index Model (HPPIM) (Haan and Diewert, 2013). The price index is computed by the estimated pooled time dummy regression equation. The negative or positive value of the time dummy parameter indicates the effect of "time" on the logarithm of the price. The value of the price index is estimated from the model by exponentiating the time dummy coefficient. It provides a quality adjusted price change between the base period 0 , and each comparison period, t. HTDRM can then be integrated within the Spatial Longitudinal Hedonic Model (SLHM) for capturing the variability of the property price due its location (Clapp, 2004). The heritage property price index model to be adopted in this study is illustrated as follows:

$$
\begin{gathered}
\ln S P_{i t}=\text { QUARTER } R_{i t} \gamma+\ln L A N D_{i t} \beta+\gamma_{1} \text { lat }_{i t}+\gamma_{2} \text { lon }_{i t}+\gamma_{3} \text { lat }_{i t}^{2}+\gamma_{4} \text { lon }_{i t}^{2} \\
+\gamma_{5} \text { latlon }_{i t}+\varepsilon_{i t}
\end{gathered}
$$

The dependent variable in this model is the transacted price in the logarithmic form $(\ln S P)$, and follows the independent variables such as the time parameter (QUARTER), land area of the transacted property in the logarithmic form (ln $L A N D$ ), and the polynomial expansion of the locational variables (lat=latitude and lon=longitude). The price index of each quarter is obtained by exponentiating the coefficient of the time parameter.

The investment performance among several asset classes such as REITs, Stocks (KLCI), the Penang (Island) Terrace House Price Index (PPTHPI), Penang High Rise Unit Price Index (PPHRPI) and Penang (Island) Heritage Property Price Index (PPHPPI) were investigated in this study. The comparison study comprised of the expected risk and return of the respective assets. Additionally, the quality of the investment asset was examined by using the Sharpe ratio. The high value of the Sharpe ratio was preferred in the selection of the investment asset. The Sharpe ratio $\left(\mathrm{S}_{\mathrm{P}}\right)$ was derived from the division of the portfolio's expected return $\left(\overline{\mathrm{R}_{\mathrm{p}}}\right)$ in terms of the excess of risk-free rate $\left(\overline{\mathrm{R}_{\mathrm{f}}}\right)$ by its expected standard deviation $\left(\sigma_{\mathrm{P}}\right)$. It can be represented through the formula below (Best et.al., 2007).

$$
\mathrm{S}_{\mathrm{P}}=\frac{\overline{\mathrm{R}_{\mathrm{p}}}-\overline{\mathrm{R}_{\mathrm{f}}}}{\sigma_{\mathrm{P}}}
$$

The expected return of every asset was calculated based on its average quarterly return over the 10-year price change. The standard deviation or risk of the quarterly return for 5 different assets in this study were estimated. The average 
quarterly yield for the Malaysian government's bond over 10 years is the riskfree asset which was used for computing the Sharpe ratio.

\section{DATA ANALYSIS}

Two types of analysis were conducted. The first type of analysis was to analyse and determine a suitable hedonic price index model for the Penang heritage property in order to ascertain the price trend starting from 2009Q1-2018Q4. The second type of analysis was to investigate the investment quality among the assets, which had been highlighted in this study. The Sharpe ratio was adopted for assessing the investment quality of each asset.

The Penang (Island) Heritage Property Price Index (PPHPPI) was constructed through the hedonic regression model, and it was estimated using the least square method. There were 39 hedonic price index models created for capturing the price change across 40 quarters, and it started from 2009-2018. The base period for the index was 2009Q1. The statistical result of the hedonic price index model is illustrated as follows:

Table 1: Statistical Result of Hedonic Price Index Model

\begin{tabular}{crrrr}
\hline \hline Variable & Coefficient & Std. Error & t-Statistic & Prob. \\
\hline \hline C & 8.891906 & 0.299035 & 29.73533 & 0.0000 \\
InLAND & 0.795586 & 0.056579 & 14.06153 & 0.0000 \\
lat & -346997.0 & 239524.7 & -1.448690 & 0.1522 \\
lon & -540067.1 & 196737.0 & -2.745122 & 0.0078 \\
lat2 & 637.5783 & 2774.168 & 0.229827 & 0.8189 \\
lon2 & 2599.911 & 970.0003 & 2.680320 & 0.0093 \\
latlon & 3389.920 & 2142.520 & 1.582211 & 0.1185 \\
QUARTER & 0.145827 & 0.086634 & 1.683252 & 0.0971 \\
\hline \hline R-squared & 0.787632 & & & \\
Adjusted R-squared & 0.764761 & & & \\
F-statistic & 34.43890 & & & \\
Prob(F-statistic) & 0.000000 & & & \\
\hline \hline
\end{tabular}

Note: $C=$ intercept, Dependent variable: property price in logarithm form (Inp), Independent variables: Land area in logarithm form (InLAND), Coordinates in polynomial form ( $\left.X, Y, X^{2}, Y^{2}, X Y\right)$, Time dummy variable (QUARTER).

According to the output above, the price index model was acceptable because $76.5 \%$ of the variability (adjusted $\mathrm{R}$ square $=0.765$ ) for the heritage properties prices were explainable using the independent variables. This was supported by Wilhelmsson (2009), who had constructed 5 hedonic price index models with the value of an adjusted $\mathrm{R}$ square, which ranged from 0.7263-0.7785. Hülagü 
Chin Tiong Cheng, Yan Bin Tan, Wai Fang Wong, Kong Seng Lai, Koh Yu Xuan

Revealing The Investment Value of Penang Heritage Properties

et.al.(2016) also adopted a hedonic price model for estimating a Laspeyres-type of price index, giving an adjusted $\mathrm{R}$ square value of 0.641 . In addition, the land size of the the heritage property was significant with a positive impact on the property's price. In other words, heritage properties with larger land size appeared to be more expensive. Buyers were willing to spend more to buy properties with bigger land size. The location of the heritage properties also had a significant relationship towards the property price, as indicated by the p-value of less than 0.05 . For example, both variables $\mathrm{Y}$ and $\mathrm{Y} 2$ recorded a significant level of 1 percent. The price index can be obtained by exponentiating the coefficient of the time dummy variable. The results showed that the price of the heritage properties in 2009Q2 were transacted at $15.63 \%$ higher than the previous quarter. Therefore, the hedonic price index model in this research was reliable and replicable for estimating the Penang (Island) Heritage Property Price Index for the future.

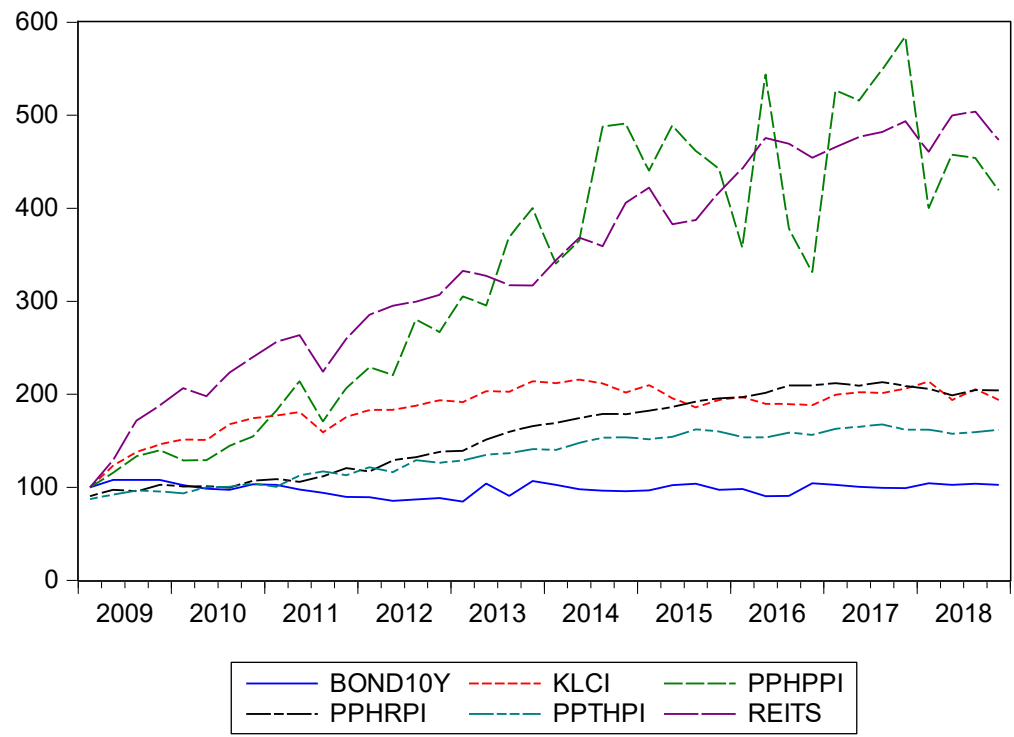

Figure 1: Quarterly Price Index of Investment Assets

Figure 1 depicts the price index of investment assets, including the Malaysian Government Bond (BOND10Y), Kuala Lumpur Composite Index (KLCI), Penang (Island) Heritage Property Price Index (PPHPPI), Penang (Island) Terrace House Price Index (PPTHPI), Penang (Island) High Rise Unit Price Index (PPHRPI) and the Malaysian Real Estate Investment Trust (REITS). Based on the graph above, REITS and PPHPPI dominated other assets in terms of capital appreciation over the past 10 years. After the Global Financial Crisis, the stock performance which is represented by the KLCI, recovered at a moderate speed, 
and the same scenario took place for the PPHRPI and PPTHPI. The momentum of the increasing trend in the PPHRPI was greater than the PPTHPI after year 2012. In Penang (Island), the investment return (percentage form) of high-rise units were much better than terraced houses.

Table 2: Quarterly Risk and Return of the Asset Classes

\begin{tabular}{c|c|c|c} 
Asset Class & \multicolumn{1}{c}{ Return } & \multicolumn{1}{c}{ Risk } & Sharpe Ratio \\
\hline REITS & $4.43 \%$ & $8.86 \%$ & 0.39 \\
\cline { 2 - 4 } PPHRPI & $2.16 \%$ & $3.43 \%$ & 0.34 \\
\cline { 2 - 4 } PPHPPI & $5.35 \%$ & $18.62 \%$ & 0.24 \\
\cline { 2 - 4 } PPTHPI & $1.66 \%$ & $3.89 \%$ & 0.18 \\
\cline { 2 - 4 } KLCI & $1.89 \%$ & $6.12 \%$ & 0.15 \\
\cline { 2 - 4 } BOND 10Y & $0.975 \%$ & - & - \\
\cline { 2 - 4 } & & &
\end{tabular}

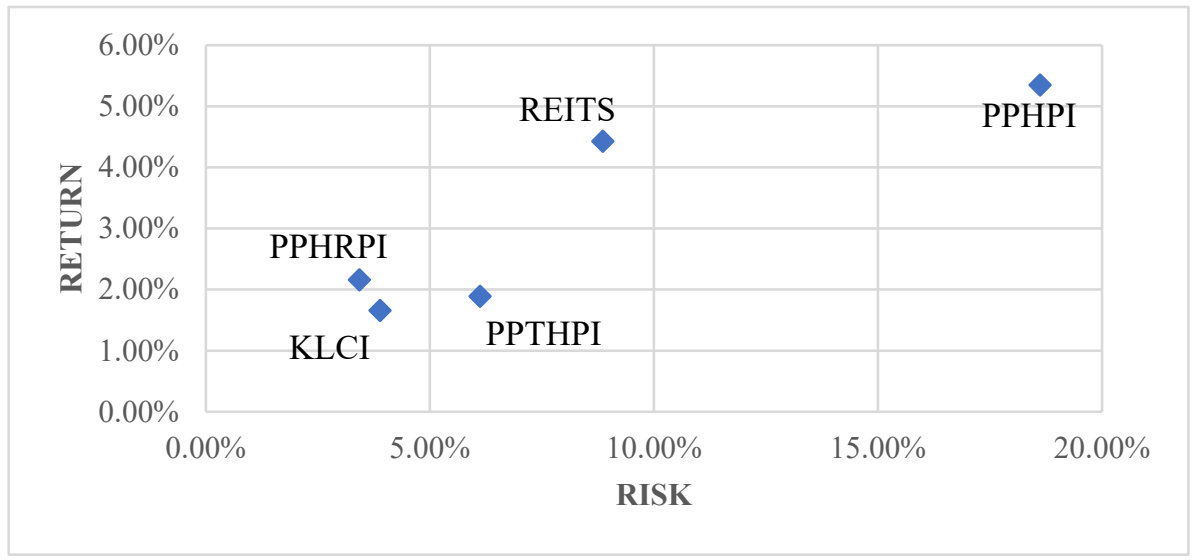

Figure 2: Quarterly Risk and Return of Investment Assets

Table 2 shows the risk and return for 5 types of investment assets. The Penang (Island) Terrace House Price Index (PPTHPI) recorded an average quarterly return of $1.66 \%$, which gave the lowest returns to the property investor. In contrast to the Penang (Island) Heritage Properties (PPHPPI), their had the highest quarterly average return of $5.35 \%$ among all of the assets. However, the risk of investing in the heritage properties appeared to be higher than other assets, especially the conventional properties such as the Terrace House and High-Rise Units. Furthermore, REITS had a better investment quality as indicated by the Sharpe ratio of 0.39 . It provided the optimal risk and return trade-off among the assets. Although PPHPPI obtained the highest average quarterly return over the 
Chin Tiong Cheng, Yan Bin Tan, Wai Fang Wong, Kong Seng Lai, Koh Yu Xuan

Revealing The Investment Value of Penang Heritage Properties

past 10 years, the price change of the heritage properties were extremely volatile, and resulted in a Sharpe ratio of 0.24.

\section{CONCLUSION}

In conclusion, this study constructed a hedonic price index model that is able to capture the price trend of Penang (Island) Heritage Properties. The model is acceptable in predicting the price index of heritage properties, as indicated by the adjusted $\mathrm{R}$ square of 0.765 . The result is supported by results from previous studies. The average quarterly return of the Penang heritage properties dominated other conventional investment assets, such as stocks, REITS, terrace houses, and high-rise units. However, the investment of heritage properties must be exercised with much more caution, as it is much riskier than other conventional assets.

\section{ACKNOWLEDGEMENTS}

This research is fully supported by the Tunku Abdul Rahman University College Internal Research Grant (UC/I/G2019-00058).

\section{REFERENCES}

Ashworth, G. J. (2002) 'Conservation designation and the revaluation of property: The risk of heritage innovation', International Journal of Heritage Studies, 8(1), pp. 9-23. doi: 10.1080/13527250220119901.

Best, R. W., Hodges, C. W. and Yoder, J. A. (2007) 'The Sharpe Ratio and Long-Run Investment Decisions', The Journal of Investing, 16(2), pp. 70-76. doi: 10.3905/joi.2007.686413.

Billington, R. (2004) 'Federal leverage attracts private investment at US heritage sites: A case study', International Journal of Heritage Studies, 10(4), pp. 349-359. doi: $10.1080 / 1352725042000257375$.

Brown, G. R. and Matysiak, G. A. (1995) 'Using commercial property indices for measuring portfolio performance', Journal of Property Finance, 6(3), pp. 27-38. doi: 10.1108/09588689510101667.

Callender, M. et al. (2007) 'Risk reduction and diversification in UK commercial property portfolios', Journal of Property Research, 24(4), pp. 355-375. doi: 10.1080/09599910801916279.

Campbell, R. J. (2009) 'Art as a Financial Investment', Collectible Investments for the High Net Worth Investor, (December 2009), pp. 119-150. doi: 10.1016/B978-012-374522-4.00006-8.

Clapp, John M. 2004. A semiparametric method for estimating local house price indices. Real Estate Economics 32: 127-60.

Cores, H. C., Assets, C. H. and Development, S. (2012) Economics uniqueness.

Elton, E. J. and Gruber, M. J. (1997) 'Modern portfolio theory, 1950 to date', Journal of Banking and Finance, 21(11-12), pp. 1743-1759. doi: 10.1016/S03784266(97)00048-4.

Fraser, W. D., Leishman, C. and Tarbert, H. (2002) 'The long-run diversification attributes of commercial property', Journal of Property Investment \& Finance, 
20(4), pp. 354-373. doi: 10.1108/14635780210435047.

Ghazali, M. F., Lean, H. H. and Bahari, Z. (2015) 'Sharia compliant gold investment in Malaysia: Hedge or safe haven?', Pacific Basin Finance Journal.

Elsevier B.V., 34, pp. 192-204. doi: 10.1016/j.pacfin.2014.12.005.

Gilderbloom, J. I., Hanka, M. J. and Ambrosius, J. D. (2009) 'Historic preservation's impact on job creation, property values, and environmental sustainability', Journal of Urbanism, 2(2), pp. 83-101. doi: 10.1080/17549170903056821.

'Handbook on Residential Property Price Indices' (2013) Handbook on Residential Property Price Indices. doi: 10.1787/9789264197183-en.

Halim, U. L., \& Tambi, N. (2021). Awareness Of Community On The Conservation Of Heritage Buildings In George Town, Penang. Planning Malaysia, 19(1), pp. 114 126. doi:10.21837/pm.v19i15.929

Hiang Liow, K. and Adair, A. (2009) 'Do Asian real estate companies add value to investment portfolio?', Journal of Property Investment and Finance, 27(1), pp. 42-64. doi: $10.1108 / 14635780910926667$.

Hülagü, T. et al. (2016) 'A Hedonic House Price Index for Turkey', (03), pp. 1-22.

Jasme, N., Othuman Mydin, M. A. and Sani, N. M. (2014) 'Investigation of Adaptive Reuse of Heritage Buildings in Penang', SHS Web of Conferences, 11, p. 01007. doi: $10.1051 /$ shsconf $/ 20141101007$.

Jin, C., Grissom, T. V. and Ziobrowski, A. J. (2007) 'The mixed asset portfolio for asiapacific markets', Journal of Real Estate Portfolio Management, 13(3), pp. 249256.

Keng, T. A. N. Y. E. N. (no date) 'THE ROLE OF RESIDENTIAL PROPERTY IN PERSONAL INVESTMENT PORTFOLIOS: THE CASE OF MALAYSIA University of Western Sydney University of Technology MARA', 10(4).

Kouwenberg, R. and Zwinkels, R. (2014) 'Forecasting the US housing market', International Journal of Forecasting. Elsevier B.V., 30(3), pp. 415-425. doi: 10.1016/j.ijforecast.2013.12.010.

de la Torre, M. (2013) 'Values and Heritage Conservation', Heritage \& Society, 6(2), pp. 155-166. doi: 10.1179/2159032x13z.00000000011.

Lazrak, F. et al. (2014) 'The market value of cultural heritage in urban areas: An application of spatial hedonic pricing', Journal of Geographical Systems, 16(1), pp. 89-114. doi: 10.1007/s10109-013-0188-1.

Lee, C. L. (2007) 'The role of Malaysian securitised real estate in a mixed-asset portfolio', (December). doi: 10.1108/13664380911000440.

Lee, C. L. (2014) 'The inflation-hedging characteristics of Malaysian residential property', International Journal of Housing Markets and Analysis, 7(1), pp. 6175. doi: 10.1108/IJHMA-10-2012-0053.

Leung, A. (2010) 'Commercial property as an inflation hedge: An Australian perspective', Pacific Rim Property Research Journal, 16(1), pp. 97-115. doi: 10.1080/14445921.2010.11104297.

Li, L. H. and Ge, C. L. (2008) 'Inflation and housing market in Shanghai', Property Management, 26(4), pp. 273-288. doi: 10.1108/02637470810894902.

Limmack, R. J. and Ward, C. W. R. (1988) 'Property returns and inflation', (November 1987), pp. 47-55.

Mat Zin, N., Ismail, S. and Md. Azmi, F. A. (2018) 'Ascertaining the Economic 
Chin Tiong Cheng, Yan Bin Tan, Wai Fang Wong, Kong Seng Lai, Koh Yu Xuan

Revealing The Investment Value of Penang Heritage Properties

Sustainability of Heritage Property Market based on Sales Transaction Analysis', Environment-Behaviour Proceedings Journal, 3(7), pp. 0-7. doi: 10.21834/ebpj.v3i7.1299.

Newell, G. (1996) 'The inflation-hedging characteristics of Australian commercial property : 1984-1995', 7(1), pp. 6-20.

Palmquist, Raymond B and Smith, V. K. (2001) 'The Use of Hedonic Property Value Techniques for Policy and Litigation', International Yearbook of Envrionmental and Resources Economics, 6, p. 78.

Patel, K. and Sing, T. F. (2000) 'Implied volatility in the U.K. Commercial property market: Empirical evidence based on transaction data', Journal of Real Estate Finance and Economics, 20(1), pp. 5-24. doi: 10.1023/A:1007824720502.

Rahman, S. (2018) 'Emerging built heritage commodification of boutique hotels in world heritage site: Evidence from George Town, Penang, Malaysia', Planning Malaysia, 16(4), pp. 104-116. doi: 10.21837/pmjournal.v16.i8.542.

Rosen, S. (2019) 'Hedonic prices and implicit markets: Product differentiation in pure competition', Revealed Preference Approaches to Environmental Valuation Volumes I and II, pp. 5-26.

Samadi, Z. and Yunus, R. M. (2012) 'Conflict of Image and Identity in Heritage Commercialization', Procedia - Social and Behavioral Sciences, 50(July), pp. 675-684. doi: 10.1016/j.sbspro.2012.08.070.

Shipley, R. (2000) 'Heritage designation and property values: Is there an effect?', International Journal of Heritage Studies, 6(1), pp. 83-100. doi: $10.1080 / 135272500363760$.

Tarbert, H. (1996) 'Is commercial property a hedge against inflation ? A cointegration approach', 7(1), pp. 77-98.

Ting, K. H., Zhou, S. Z. and Bao, H. X. H. (2007) '12th Asian Real Estate Society Annual Conference Regional Variations of Residential Real Estate Returns in Malaysia Regional Variations of Residential Real Estate Returns in Malaysia', Policy, (July).

Tokede, O., Udawatta, N. and Luther, M. (2018) 'Retrofitting heritage office buildings in the UK: a case study', Built Environment Project and Asset Management, 8(1), pp. 39-50. doi: 10.1108/BEPAM-11-2016-0068.

Wilhelmsson, M. (2009) 'Construction and updating of property price index series: The case of segmented markets in Stockholm', Property Management, 27(2), pp. 119 137. doi: 10.1108/02637470910946426.

Worthington, A. C. and Higgs, H. (2004) 'Art as an investment: Risk, return and portfolio diversification in major painting markets', Accounting and Finance, 44(2), pp. 257-271. doi: 10.1111/j.1467-629X.2004.00108.x.

Received: $12^{\text {th }}$ July 2021. Accepted: $17^{\text {th }}$ Sept 2021 